
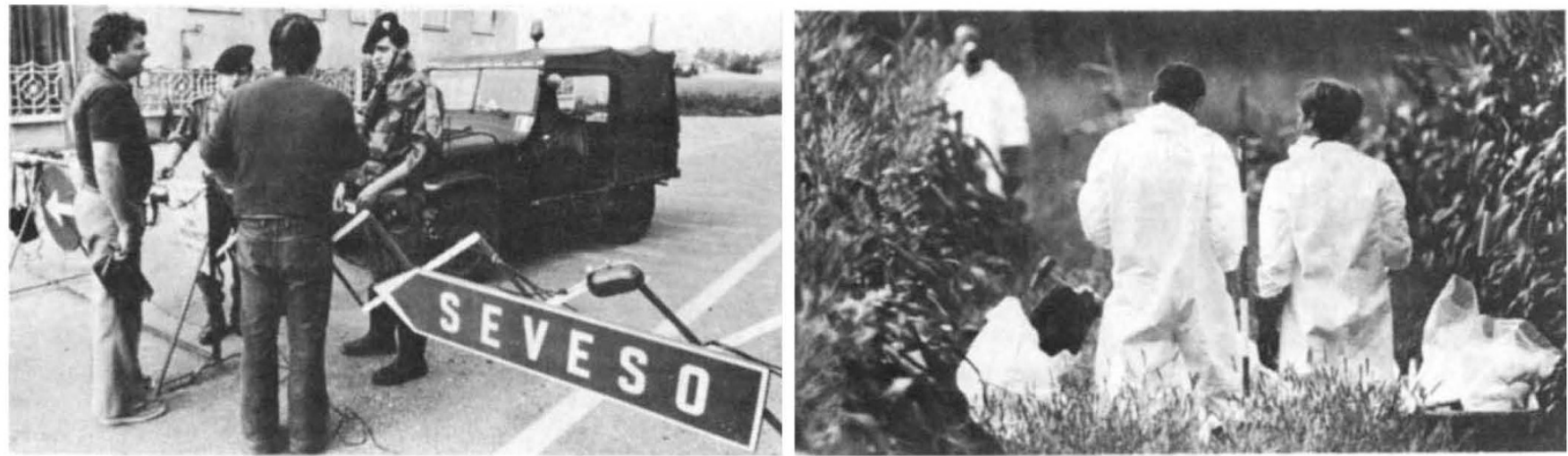

\title{
Italian Commission covered up Séveso delays
}

\section{Italy's official report on the Séveso accident leaves out some important information, writes Alastair Hay}

THE 412 page Italian Parliamentary Commission Report on the accident at Séveso in Italy in July 1976-an accident in which tetrachlorodibenzodioxin (dioxin) from ICMESA's trichlorophenol reactor was discharged over a populated area-should have been the definitive report on the episode. But documents in Nature's possession indicate that the claims of Givaudan-a subsidiary of F. Hoffmann la Roche and the owner of the reactor-are more accurate than those of the commission's report

The bitter and continuing disagreement centres on the sequence of events between 10 July 1976, when the Séveso accident occurred and 24 july when evacuation of the dioxincontaminated area was ordered. Givaudan claims that it was responsible for urging the authorities to evacuate the area. But the commission's report assigns a far more important role to Italian scientists in recognising the danger. Another report however, that of the Lombardy Regional Government supports Givaudan's claims and indicates that the Italian Parliamentary Commission omitted some vital evidence in its report.

Few would disagree that the twoweek delay in ordering the evacuation of residents may have had serious consequences for health. The Italian authorities claim that the delay was the result of a lack of information on the extent of the dioxin contamination. According to the Parliamentary Commission report it was not until the evening of $23 / 24$ July that "positive evidence of the presence" of dioxin was obtained from the results of analyses performed by the Italian laboratories-the Superior Health Institute in Rome and the Provincial Laboratory of Hygiene and Prophylaxis (PLHP) in Milan.

The full version of the commission's report--only recently made available to interested parties-differs substantially from the summary made available to the press by the Italian authorities when the report was presented to the Italian Parliament in June 1978. The press version implies that the Italian laboratories found dioxin and that their results were used as the basis for ordering the evacuation.

The account in the full report, however, says that two Italian scientists, Drs Ghetti and Cavalloro, flew to Givaudan's laboratory at Dubendorf, near Zurich on 19 July and there received confirmation that dioxin had been discharged into the atmosphere at Séveso. They immediately returned to Italy and duly informed the various authorities. Meetings were held in the days following, and arrangements made for monitoring the situation. It was not until a meeting on 24 July, under the chairmanship of the Health Assessor Dr Rivolta, that the evacuation was ordered. The Italian laboratory results were presented at the meeting, says the report, and confirmed by the Givaudan representative, Dr Vaterlaus.

However, neither the commission nor the press release versions are supported by official reports of the Health Assessor's Council (HAC) of the Regional Board of the Lombardy Region. One controversial issue is the question of whether the ICMESA management notified the appropriate authorities about the accident and its potential seriousness on 10 July. The main HAC report says that it did. All reports confirm that it was the 15 July when the first order was posted by the local mayor to warn the population about the contamination and banning the "consumption of fruit and vegetable products" grown in the vicinity of the factory.

On 18 July, says the HAC report Dr Cavalloro, Director of the PLHP in Milan, suspected the presence of dioxin in the discharge from the reactor. His suspicion was confirmed by ICMESA although the parent company, Givaudan, says the report, "does not admit that there is dioxin; it allows this to be understood". Under the entry for $20 \mathrm{July}$, the HAC report says that on the previous evening Drs Cavalloro and Ghetti, during their visit to Givaudan's research laboratories outside Zurich, received confirmation from the company of the "qualitative presence of TCDD [dioxin] outside the factory". Nature also possesses the data that Givaudan claims was provided to both scientists. It consists of a map outlining an area of dioxin contamination, based on the results of analyses of some 36 environmental samples.

For the next two days, the 21 and 22 July, both the Parliamentary Commission and Lombardy Region reports are in agreement. However, on the 23 July they differ substantially. The HAC report assigns a greater involvement to Givaudan and Roche in the Lombardy Regional Government's deliberations than does the commission's report. It says that on 23 July a representative of Roche arrived at an extraordinary meeting of the Provincial Health Council in Milan where various Italian scientists with an interest in Séveso were considering

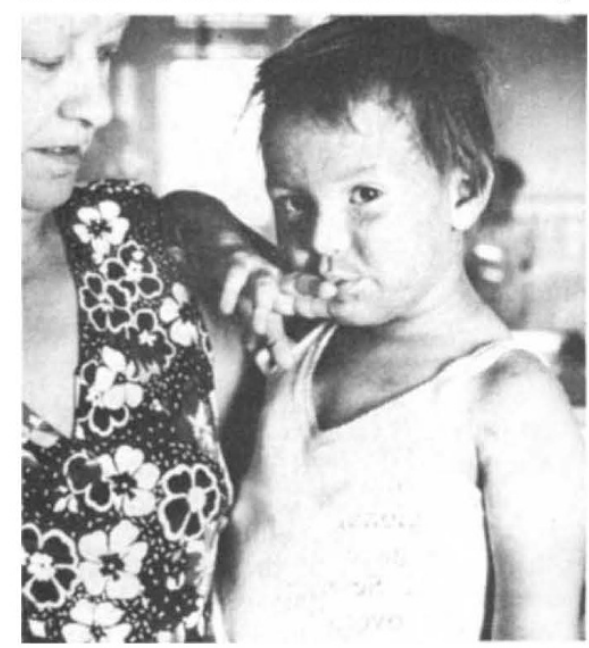

Child exposed to dioxin 
the measures to be adopted and was forbidden to speak. Later that day at another meeting-of the local administrators of the Séveso region-the representative, Dr Guiseppi Reggiani, Director of Clinical Research for Roche, stressed to the Health Asessor, Dr Rivolta, the necessity and urgency of evacuating the population at Séveso exposed to the highest concentrations of dioxin. Rivolta asked him to put his concern in writing. The report says that this request was complied with on 24 July in a letter (signed by Givaudan's president, Dr Guy Waldwogel). At the same time, the report adds, a map of the polluted area was handed over, with the first quantitative data on the pollution released by Givaudan. The map contained the results of analyses of 44 environmental samples. The Lombardy Region report suggests therefore, that Givaudan and Roche played a far larger role in documenting the pollution at Séveso than the Parliamentary Commission gives them credit for.

On the 19 July however, Givaudan claims that the two Italian scientists Ghetti and Cavalloro, who visited the company's laboratory near Zurich, received most of this data-albeit from some 36 environmental samples. If this is true why does the Parliamentary Commission report not mention it? (Nature has ascertained that this information was presented to the commission during a six hour meeting) and why had the Italian authorities not even considered an evacuation by 23 July when they knew of the dioxin contamination on 20 July?

The Parliamentary Commission report admits that the laboratory facilities and expertise required to assess dioxin contamination at Séveso were not available in Italy. This is one reason why Ghetti and Cavalloro were provided with the necessary dioxin standards when they visited Givaudan on 19 July. Dr Cavalloro declined to tell Nature the number of measurements his laboratory had made between 20 July and 11.00 p.m. on 23 July. Asked about the differences between the reports of the Parliamentary Commission and Lombardy Region he felt he was not competent to answer and that as it was a political question it should be directed to the Lombardy Regional Government. $\mathrm{He}$ and his colleagues, he said, were "only technicians".

Signor Cesare Golfari, President of the Lombardy Regional Government told Nature that he thought the Parliamentary Commission Report was "good for the Regional Government". In his opinion, it gave an adequate account of events at Séveso. Roche, too, welcomes the overall objectivity of the commission's report-the commission was eqaully scathing of Roche, Givaudan and many of the Italian authorities. A spokesman for Roche, however, described the commission's report as telling a "twisted tale". He said that he "certainly" knew that the commission's charge that Givaudan had not informed its workers at ICMESA about the hazards of dioxin was true. He also said that all but 6 or 8 of some 6,000 civil claims for damages against Roche had been settled and conceded that the lawyers had recommended prompt settlement of claims to avoid a higher bill if the criminal court case went against the company.

The criminal prosecution is in the hands of the Italian Judiciary. The court will consider whether or not Givaudan was negligent in its main- tenance of the trichlorophenol reactor at Séveso, and whether it could have informed people more quickly after the accident of the danger they faced. The hearing is unlikely to take place for some time however, for the judge originally appointed to deal with the case has recently been promoted and his successor will need some time to familiarise himself with the background to the case.

Until the court hearings are available, the Parliamentary Commission report will remain the most comprehensive appraisal of the accident at Séveso. Britain's Health and Safety Executive (HSE), is to have the document translated. When that is available much of what happened at Séveso will be available for public scrutiny outside Italy.

\section{Genetic manipulation: Britain may exempt "self-cloning"}

Britain's Genetic Manipulation Advisory Group will meet this week to reconsider issues which have been bothering the group for some timeparticularly the definition of genetic manipulation and whether it should include "self-cloning" experiments.

These are experiments in which the genes of a bacterium are cloned within the bacterium itself-such as $E$. coli within $E$. coli-which are already exempted from control under the revised US National Institutes of Health guidelines.

GMAG has been under considerable pressure from bacteriologists-and lately the Royal Society (see Nature, 15 February, page 509)-to relax its control of such experiments, which form a substantial proportion of potential recombinant DNA research: and now it appears to be responding. Even if GMAG decides in favour of a strict definition of recombinant DNA experiments which includes selfcloning, it is felt that it will move to cxempt the experiments from categorisation.

At its last meeting GMAG decided "in principle" to adopt the new risk assessment scheme devised by Sydney Brenner--but only for a trial period of about one year. Four proposals for experiments have already been received for consideration by risk assessment, including one application for downgrading, and two have already been assessed. In these cases the categorisation was the same as it would have been under the phylogenetic Williams guidelines, so there was no conflict, but members of GMAG are known to be worried about cases where there is disagreement. It is felt that much is yet to be learned about real risk factors. and that much more research on them needs to be undertaken before risk assessment can be firmly established.

Meanwhile the "technical panel"which will make the assessments and advise the Medical Research Council and Health and Safety Executive on risk research that needs to be undertaken-is being established under the chairmanship of Professor Peter Walker of the University of Edinburgh, a man who has been not uncritical of excessive control of recombinant DNA research.

The technical panel will have some nine "core" members, including representatives of GMAG and outside experts, and will also co-opt special expertise when necessary.

This week's meeting of GMAG will be a particularly interesting one for it may be the first at which the deeper views of its seven now members (out of a total of 19) will be tested. The last meeting was concerned with a detailed discussion of the risk assessment scheme, and like many of the regular GMAG meetings it failed to address--or at least reach decisions on - certain matters of principle such as the basic definition of its area of competence. Hence this week's extraordinary meeting, called specifically to address these questions.

If the meeting reaches its conclusions ranidly. GMAG will publish a short document for researchers outlining its new policy. A full note will be issued in due course.

Robert Waigate 